\title{
5. United Kingdom: the politics of government survival
}

\author{
Justin Pritchard
}

\section{From Northern Rock to a global financial crisis}

For the United Kingdom in early 2007, the US credit crisis seemed to be a foreign concern. By August, however, the French bank BNP Paribas, one of the largest banks in the eurozone, announced to investors that they would be unable to withdraw funds from two of the bank's hedge funds; and by September 2007, when British bank Northern Rock requested emergency financial support from the Bank of England, the credit crisis had hit home. The significance of this development was magnified by the fact that Northern Rock's troubles were first brought to public attention not by the government, but by the media. On 14 September, the day after the BBC Economics Editor Robert Peston had broken the Northern Rock story, depositors withdrew £l billion from the bank-the largest run on a British bank for more than a century. So, from the first very public manifestation of the credit crisis in the United Kingdom, the media had set the agenda and the government was on the back foot. In 2008, more British institutions announced multi-billion-pound exposures to the US credit crisis, including the Royal Bank of Scotland (RBS) in April, Barclay's and Halifax Bank of Scotland (HBOS) in July and Bradford \& Bingley in August. In response to these developments, the British Government nationalised Northern Rock in February 2008 and partly nationalised Bradford \& Bingley in September 2008 and HBOS, Lloyd's and RBS in October 2008.

This chapter focuses on three key actors responsible for managing the global financial crisis in the United Kingdom: Prime Minister Gordon Brown, Chancellor of the Exchequer Alistair Darling, and Bank of England Governor Mervyn King. As well as buying up risky assets and nationalising financial institutions, these three implemented a number of fiscal and monetary responses to the crisis. Brown and Darling cut the value-added tax (VAT) from 17.5 per cent to 15 per cent, raised the aged pension and offered new tax breaks. Together with King, they injected $£ 300$ billion into the financial system. King, who before 2007 was a fairly low-profile technocrat, presided over a slash in the official bank interest rate from 5.75 per cent in August 2007 to a historic low of 0.5 per cent in March 2009 (Kollewe 2009b). By this time, King had become a prominent public figure.

From 2007 into 2009, the British political landscape was dominated by economic turmoil. Contextual factors of this period are, however, worth noting. Brown's 
succession to the prime ministership in June 2007 failed to have much of an impact on the low approval ratings the 10-year-old Labour Government had endured since late 2005 (UK Polling Report 2009). Brown's failure to reinvigorate Labour's support base can be attributed in part to his role as Chancellor of the Exchequer throughout the entirety of the reign of former Prime Minister, Tony Blair. As one pundit phrased it particularly colourfully, Brown and Blair appeared 'as two cheeks of the same arse' (Galloway 2006). Despite a brief increase in Brown's popularity after the Northern Rock crisis, in July 2008, it was widely reported in the British press that Secretary of State for Foreign and Commonwealth Affairs David Miliband, would challenge Brown for the leadership. Miliband, however, made a tactical blunder and the challenge did not materialise. Throughout 2008, however, Brown's popularity steadily declined, sitting consistently 12-16 points behind the Conservative Party leader David Cameron, as preferred prime minister (UK Polling Report 2009).

Since replacing Brown as Chancellor of the Exchequer in June 2007, Alistair Darling was scrutinised for more than just his handling of the financial crisis. In November 2007, Darling announced that the Revenue and Customs Department had lost two data discs containing the records of 25 million citizens claiming child-benefit assistance ( $B B C$ 2007). This incident damaged confidence in the Chancellor just as the financial crisis was taking hold (see Times 2007). Just as it had for Brown, the media reported that Darling would be challenged for the Chancellorship by the Secretary of State for Children, Schools and Families Ed Balls, after the 2008 local UK elections (Mulholland 2008). While this challenge also failed to materialise, the intra-party division and the spectre of leadership challenges are important contextual factors when investigating Brown's and Darling's responses to the financial crisis.

\section{Box 5.1 The United Kingdom's financial crisis trajectory, September 2007 - March 2009}

I3 September 2007: BBC Business Editor Robert Peston, breaks the story that Northern Rock has secured emergency financial support from the Bank of England (BOE). Northern Rock had relied on market investments, rather than savers' deposits, to fund its mortgage lending.

I4 September: Northern Bank depositors withdraw £l billion-the biggest run on a British bank for more than a century.

I7 September: Northern Rock's shares have fallen precipitously since 14 September. The government announces that it will guarantee all savings of Northern Rock depositors.

I9 September: The BOE breaks with its previous position not to inject any funding into financial markets and pumps $£ 10$ billion into the system. 
I5 November: Barclay's Bank announces a $£ 1.3$ billion exposure to the US sub-prime mortgage collapse.

29 November: The BOE announces that the number of mortgage approvals has fallen to a three-year low.

6 December: The BOE slashes interest rates by 0.25 per cent to 5.5 per cent.

I2 December: The world's five largest central banks announce an unprecedented $\$ 110$ billion lifeline to commercialise banks over Christmas, of which $£ 10$ billion is given to the British banks.

2I January 2008: Global stock markets, including London's FTSE 100 index, experience their worst falls since 11 September 2001.

7 February: The BOE slashes interest rates by 0.25 per cent to 5.25 per cent.

I7 February: The government announces that it has knocked back the bid of Richard Branson's Virgin Group to take over Northern Rock, and nationalises the bank.

3 March: The amount in sub-prime loans being written off by HSBC rises to $£ 51$ million a day - a sign of trouble to come for the London-based bank.

Io April: The BOE slashes interest rates by 0.25 per cent to 5 per cent. 22 April: The RBS announces the biggest rights issue in UK corporate history: $£ 12$ billion. It also writes off $£ 5.9$ billion of assets.

22 April: HBOS announces a $£ 4$ billion rights issue.

I4 May: Bradford \& Bingley announces a $£ 300$ million rights issue.

25 June: Barclay's Bank announces for sale a round of discounted shares, intended to raise $£ 4.5$ billion.

I July: UK annual house prices suffer their biggest fall since 1992.

2I July: The HBOS rights issue receives little enthusiasm from shareholders, forcing the company's underwriters to purchase the remaining shares for $£ 4$ billion.

I7 September: Lloyd's Banking Group offers $£ 12$ billion to acquire HBOS.

29 September: Bradford \& Bingley is nationalised, although its savings operations and branches are sold to Spain's Santander Bank.

3o September: The government announces that it will raise the limit of guaranteed bank deposits from $£ 35,000$ to $£ 50,000$. 
6 October: The Icelandic Government announces a rescue package to save its banking sector and forces its banks to sell off its foreign assets.

8 October: The UK Government threatens legal action against the Icelandic Government to retrieve UK citizens' savings tied up in Iceland's banking sector. The UK Government announces a $£ 50$ billion rescue package of the UK banking system.

9 October: The UK Government announces plans to freeze assets of Icelandic companies in the United Kingdom under anti-terrorism legislation.

I3 October: The UK Government provides $£ 37$ billion to HBOS, the RBS and Lloyd's Banking Group, beginning a takeover of the former two by Lloyd's that concludes in January 2009.

I5 October: UK jobless figures experience their biggest rise in 17 years. I6 October: The FTSE hits a five-year low: 3850.

24 October: The UK Office of National Statistics announces that the United Kingdom is on the brink of a recession, revealing that the economy contracted in the third quarter of 2008.

6 November: The BOE radically slashes the official bank rate from 4.5 per cent to 3 per cent - the lowest interest rate level since 1955.

24 November: Alistair Darling announces in his pre-budget report that the VAT will be cut from 17.5 per cent to 15 per cent, while the UK Government's borrowing will increase. The government also announces plans to inject $£ 20$ billion into the economy in 2010 - representing 1 per cent of gross domestic product (GDP).

4 December: The BOE slashes the official interest rate by another full percentage point to 2 per cent - the lowest level in 57 years.

I7 December: The UK Office of National Statistics announces that there are now 1.86 million Britons without work, making the jobless figure- 6 per cent - the highest in more than a decade.

3I December: The FTSE 100 closes down 31.3 per cent since the beginning of 2008 - the biggest annual fall since the index began in 1984.

8 January 2009: Having existed for 315 years, the BOE slashes interest rates to an all-time low of 1.5 per cent.

I9 January: The government announces a second bank rescue package worth $£ 50$ billion. 
5 February: The BOE slashes interest rates once again to another record low of 1 per cent.

6 February: The BOE announces a plan to lend directly to credit-starved companies, aimed at bypassing the banks altogether.

I8 March: The International Monetary Fund (IMF) announces that it expects the UK economy to continue to contract in 2010 even as other economies begin growing again. It predicts that the UK economy will contract by 3.8 per cent in 2009 .

I9 March: Adair Turner, head of Britain's Financial Services Authority (FSA), releases his report on Britain's regulatory structure and the global financial crisis. In it he says that, with hindsight, the FSA and the national regulatory system had a number of key shortcomings.

24 March: Figures show that the United Kingdom's jobless figure is rising above two million for the first time since 1997.

\section{Methodological considerations}

The focus of this chapter is the period of April 2008 to March 2009, when the 'credit crunch' turned into what has been widely described as the worst global financial crisis since the Great Depression. Since the United Kingdom experienced the first effects of the global financial crisis in September 2007, this chapter summarises the early rhetoric of each actor. Exploring their early crisis framing establishes how much room each actor left himself to manoeuvre when the crisis worsened through 2008. The speeches analysed within this chapter were sourced from the official web sites of the individual or their institution. The speeches were identified as being significant because of their heavy use of crisis-exploitation rhetoric, but also because most of them received considerable media coverage. It is worth noting that Darling's and King's web sites did not provide a wide range of their speeches and were missing some speeches that had been mentioned in the media. This meant that not only was the choice of speeches somewhat limited, the Chancellor and the bank governor had, by omitting some speeches from their web sites, signalled that others were the ones intended for public consumption.

The chapter attempts to gauge the media and public response to the crisis exploitation of the three actors through a survey of three newspapers that represent a fair spectrum of British society: The Guardian/Observer, The Times and the Financial Times. The Guardian (circulated Monday to Saturday) and its sister paper, The Observer (circulated on Sundays), owned by the public non-profit Scott Trust, currently have circulations of about 400,000 (Guardian 2009). They are typically seen as left leaning. Whereas 80 per cent of The Guardian/Observer readership voted Labour in 2000, a 2005 survey showed that 
only 48 per cent voted Labour. This figure was likely to be even lower by 2008 given the further slide in Labour's popularity (Ipsos Mori Poll 2005).

The Times, owned by News Corporation and historically the best-known UK paper, has a circulation of 617,000 . Its Sunday edition momentarily has a circulation of 1.2 million (Guardian 2009). For decades, it took a centre-right political stance, but in the 2001 and 2005 elections, it supported the Labour Party. The Daily Telegraph, a paper with a political stance further right than The Times and a slightly larger overall readership, was not selected for analysis because of its limited coverage of the global financial crisis. The Financial Times has a lower circulation than the aforementioned papers, but offers a deeper level of economic insight to the crisis. It is owned by the education and media conglomerate Pearson PLC and generally adopts free-market stances (Financial Times 2009b). All three selected papers are published in London. When attempting to track the media and public response to the three key actors' crisis rhetoric, however, the cross-section of ideological views was deemed to be more important than a regional interpretation of the crisis.

\section{Crisis development and elite rhetoric in the United Kingdom}

\section{October 2007: Prime Minister Brown's 'age of turbulence' speech}

In the weeks after the 14 September run on Northern Rock, all major British polls (UK Polling Report 2009) calculated that Labour had extended its 3-5-point lead to 6-13 points despite some considerable media criticism of its handling of the crisis (Pratley 2007). Brown's, and Labour's, surge in the polls, however, proved to be remarkably short-lived; by October 2007, the Conservative Party had become the preferred government (UK Polling Report 2009). It was against this backdrop that Brown delivered his earliest keynote speech on the downturn in world financial markets.

Certainly, it would be unreasonable to expect that Brown could have known of the scale of the global financial crisis that was to emerge one year later. Nonetheless, his speech was noteworthy insofar as Brown clearly gave his British audience some expectations about the strength of Britain's economy and its ability to confront future turmoil. This early speech was significant because it affected his room to manoeuvre in subsequently framing the global financial crisis as it entered a more severe phase in September 2008. Brown acknowledged that the downturn in financial markets throughout 2007 was a concerning sign and imputed responsibility for this downturn primarily to global economic factors and partially to the irresponsibility of 'those who own and run banks' in Britain. He also emphasised the need to make 'changes in the financial system globally as well as nationally'. 
Brown attempted to normalise the Northern Rock crisis in what he described as the modern 'age of turbulence', in which 'turbulence is the essence of the financial system'. This was an early attempt to defend the economic approach based on free markets taken by 'New Labour' since its election victory in 1997. Brown's speech lauded former US Federal Reserve Chairman Alan Greenspan (whom Brown was introducing at the Reuters Building) and he agreed with Greenspan's statement that the market was now 'more...self-correcting...than it was even a quarter of a century earlier', and claimed that this approach had given Britain 'greater flexibility...to adjust when events threaten our [Britain's] growth'. Brown warned of the dangers of governments around the world 'responding with heavy-handed regulation' and thereby defended the economic status quo. In denouncing protectionism, he furnished the historical analogy of the Enron and WorldCom crashes in the United States, to which the United Kingdom 'did not respond with heavy-handed regulation'.

One notable assessment of Brown's speech came from a Guardian journalist who acknowledged that Northern Rock's directors were at fault, but criticised Brown's complete denial of responsibility for the crisis. 'Gordon Brown, a man who claims to be a master of prudent financial management while presiding over a debt-addicted and unbalanced economy, must bear a share of the responsibility' (Sunderland 2007). Despite Brown's intent to have this speech seen as a major statement on the economy, it did not receive significant press coverage. Much of the media concentrated instead on Brown's lead in the polls and the possibility that he would call an early election.

\section{September 2007 - February 2008: Chancellor Darling's early rhetoric}

After just three months as Chancellor of the Exchequer Alistair Darling was confronted with the largest run on a British bank in more than a century. Public confidence in the nascent Chancellor was dented by the fact that the British Broadcasting Corporation (BBC), not the government, had broken the story to the public. Furthermore, after the withdrawal of $£ 1$ billion in savings from Northern Rock, it took Darling three days to announce that the government would guarantee all deposits up to $£ 35,000$.

After the Northern Rock crisis and announcements in late 2007 by more British banks of multi-billion-pound exposures to the US sub-prime mortgage market, Darling averred that the United Kingdom was in 'uncertain' and 'turbulent times' (Darling 2007b). Nevertheless, he emphasised that the British economy was fundamentally strong and that the public could be confident that the economy would continue to grow. Darling blamed the recent downturn in world financial markets on institutions that had based their growth on risky business models, but also on factors far from British shores that damaged the globalised UK economy. Despite conceding that globalisation and free-marketism had presented 
challenges to the United Kingdom, the Chancellor declared that the UK economy had been overwhelmingly strengthened by an open and globalised approach since 1997. He also portrayed a potential retreat into protectionism as a dangerous alternative, utilising the exact historical analogy as the Prime Minister - that of the Enron and WorldCom collapses - to demonstrate that financial crises need not be met with a hyper-reactive move away from the sound fundamentals of globalisation and free markets (Darling 2007a). Darling defended the political-economic status quo and prescribed an open and globalised economic orientation as the way for Britain to make it through the financial turmoil.

Through 2007, Darling blamed the crisis on reckless British banks and global factors in equal measure, but in early 2008 he began to emphasise the latter as the predominant cause of Britain's economic downturn. By this time, Darling was also depicting the crisis in less sanguine tones. In January 2008, he stated that 'we operate in far more turbulent times' (Darling 2008a) and claimed that 'the global economy is facing its biggest test for more than a decade' (Darling 2008 b). His previous predictions that economic growth would remain high were now conspicuously absent. He did, however, maintain that the strong fundamentals of the UK economy-which were created by the Labour Government - meant that 'Britain is well placed, indeed better placed than almost any other, to see through this uncertainty' (Darling 2008a).

Overall, the press was more disapproving than supportive of Darling in this period. The three newspapers analysed in this chapter unanimously declared that the Chancellor and the Labour Government had misjudged the severity of Northern Rock's predicament and had been slow to act when depositors withdrew their savings en masse. In terms of the Chancellor's severity narrative, The Guardian wrote that Darling was underplaying the turmoil but that this was 'fair enough' considering he did not want to 'spread doom and despondency' (Elliot 2008a). The Times wrote that Darling had offered only a 'crossed-fingers' approach that the slowdown would not be too severe' (Riddell 2008a:28).

Darling's causality narrative divided opinion. The Guardian supported Darling, saying that 'neither he nor the government is the source of the Northern Rock crisis in any way' (Kettle 2008). The Financial Times, however, declared that the seed of the credit crisis was the Labour Government's ill-considered centralisation of British financial regulation in 1999 (Morley 2007:11). Darling's policy proposals prompted little media response, although The Times stated that Darling had 'little sense... [about] how in the long-term public finances will be restored to health' (Riddell 2008a:28). 


\section{September 2007 - April 2008: bank governor King's early rhetoric}

Before the North Rock crisis, Mervyn King was a technocrat known mainly to people within the financial industry and newspaper economics correspondents. His name was periodically mentioned in the general press when he announced interest rate adjustments. His profile rose exponentially, however, after the Northern Rock crisis and he became a key figure in imparting meaning to Britain's financial turmoil.

King's early pronouncements on the financial turmoil were more sober than those of the Chancellor and the Prime Minister. Immediately after the run on Northern Rock, King publicly stated that to bail out the bank would be a 'moral hazard'. Simply put, to rescue the bank with an injection of public funds would discourage responsible financial management among British companies and set a standard for bailing out a raft of irresponsible companies. This indicated King had cause to believe that Northern Rock's predicament was not an isolated one. Indeed, the Bank of England (BOE) was aware that HSBC had $£ 10.5$ billion of exposure to the US sub-prime mortgage market in February 2007 (Seager 2009). Regulatory authorities in the United Kingdom had been aware of other British banks having to write off billions of pounds worth of bad debt throughout 2007. King's rhetoric in this early period was serious, but perhaps not quite as pessimistic as he might have been behind closed doors. He used measured phrases to acknowledge the significance of the crisis while not denting consumer confidence. He explained that 'conditions were not yet back to normal and remain[ed] fragile', and that the intention of financial institutions 'to tighten conditions further' was 'unlikely to be short-lived' (King 2008a).

King's early speeches identified the sub-prime mortgage market in the United States as being the focal point of financial turmoil. King stated, 'The challenges facing us...many of them originate from outside our shores' and 'Northern Rock [was] not the epicentre of the current crisis' (King 2008a) In November 2007, King admitted that, if he had his time again, he would have done several things differently in handling the Northern Rock crisis. This acceptance of partial responsibility was oddly conspicuous compared with the complete denial of blame by Brown and Darling, and later placed less pressure on King to admit blame for not recognising the oncoming British recession (Seager 2009).

The commentary in the three papers expressed some moderate concern that King was underplaying the severity of the crisis, but the main focus was on his causality narrative and policy proposals. The Guardian argued that the Northern Rock crisis was not at all the fault of King or the BOE. The Times agreed that King did not cause the Northern Rock crisis, but pilloried his volte-face on the issue of government bailouts and claimed that the BOE significantly exacerbated the Northern Rock crisis. The Financial Times also pardoned King and the BOE 
from the charge that they were to blame for not recognising the poor business model of Northern Rock and other British banks, instead blaming the FSA. The Financial Times did, however, indirectly blame King as part of a group of influential central bankers in the developed world, whose monetary policy between 2002 and 2004 was so irresponsible that it was a key source of the present financial turmoil.

\section{March 2008: the Chancellor's budget statement}

There was much gloomy economic news in Britain at the beginning of 2008 . January had seen the biggest one-day fall of the FTSE 100 and in February there had been the last-resort nationalisation of Northern Rock and HSBC's announcement of massive exposure to the US sub-prime mortgage market. Nonetheless, the Chancellor's keynote budget speech did not alter his late-2007 description of the severity of the crisis, declaring that 'these were times of global economic uncertainty'. He reiterated the role of global factors in causing the crisis and defended the globalised, free-market orientation of the British economy.

Darling continued to predict growth for the UK economy, although the forecasts were slightly less optimistic than before. One major difference to his previous speeches, however, was that he emphasised economic 'stability' more than 'growth'. Nonetheless, Darling asserted that Britain was 'uniquely placed to succeed in the global economy' and 'enter[s] this period of uncertainty better placed than any other major economy'.

The budget was the dominant issue in the media in the week after its release, with the three major papers largely disagreeing with Darling's severity narrative. The Times called it a recklessly courageous act to continue to predict growth, while the Financial Times stated that 'like the rest of us, Alistair Darling is navigating the global economic storms without a compass' (Stephens 2008:5). The newspaper critiques of Darling's policy proposals, however, remained vague. The Financial Times argued that the budget was highly imprudent and that the 'higher borrowing figures were an embarrassment' (Stephens 2008:5). The Times stated that Darling's budget was a 'fingers-crossed' budget, but qualified this by saying that 'there is...nothing new about fingers-crossed budgets' and that this approach 'was about as good as could have been expected' in such a challenging economic climate (Kaletsky 2008:1). These newspapers indicate the scepticism and negativity surrounding the policy proposals outlined in Darling's budget speech.

\section{June 2008: King's 'normalisation' of turmoil}

Consistent with the increase in the severity of the crisis since early 2008, King described the financial milieu as 'the most prolonged period of financial turmoil that most of us can remember' — a remarkable statement given King's 40-year career as an economist. This austere statement came before the credit crisis 
evolved into the global financial crisis after the September 2008 collapse of Lehman Brothers. While this statement did maximise the severity of the crisis, it did not convey the possibility of dire systemic turmoil of which King appeared to be aware at this time.

As if to downplay the possibility that his serious description of the financial turmoil might be received with panic, King normalised the financial crisis in the context of economic history. Rather than calling the crisis 'unprecedented', as he, Darling and Brown would do in later months, he stated that 'financial crises [had] been a regular, and disturbing, feature of our and other developed economies'. He stressed that at this time there should not be a reactionary move back to the pre-1997 regulatory framework, adding that 'no framework can avoid shocks, so we must think carefully about reform'. King also insisted that 'there is no point blaming anyone for the outcomes'.

King's reluctance to identify specific actors for their culpability in the crisis might be explained by the critical scrutiny he was receiving in the press for his and the BOE's handling of the financial crisis, particularly their performance during the Northern Rock crisis. The three newspapers analysed in this chapter focused not on his causality narrative but on his policy proposals. The papers were critical of the fact that the inflation rate had overshot King's inflation target by a full 1 per cent, and were sceptical about his policy outlook for the continuing credit crisis.

\section{October 2008: the Prime Minister's ‘unprecedented times'}

Brown's October 2008 speech was markedly different in tone to his October 2007 address. By this time, the small UK banking crisis and worldwide credit crunch had morphed into the global financial crisis. Northern Rock required full nationalisation in January 2008 after the unsuitability of takeover bids. In the subsequent months, six more banks - HSBC, HBOS, RBS, Bradford \& Bingley, Lloyd's and Barclay's - had announced monumental losses (BBC 2009). Moreover, just a few days before Brown's speech, the Icelandic economy had begun to collapse, and Brown had threatened Reykjavik with legal action in a bid to retrieve savings of UK citizens tied up in Icelandic banks. The domestic political backdrop had also changed from a year before. Brown was consistently between 8 and 15 points behind Conservative leader, David Cameron, in the polls for preferred prime minister (UK Polling Report 2009).

Brown declared that 'these [are] unprecedented times'. He maximised the severity of the crisis, claiming that 'the stakes are higher than ever before'. Continuing on from his October 2007 speech, in which he had identified global financial forces as the primary cause of the Northern Rock crisis, Brown proclaimed that 'this is first and foremost a global crisis'. Furthermore, Brown defended himself, 
his government, the BOE and the FSA from charges of negligent financial regulation, stating that 'no one country alone can resolve what is truly a global problem'. Brown declared that this global crisis required a global solution, one in which there would be increased international cooperation to regulate global capital flow. Brown utilised the historical analogy of Franklin D. Roosevelt and Winston Churchill planning the revolutionary post-1945 Bretton Woods regulatory structure in the midst of World War II as a means of affirming the possibility of a new global regulatory system to be achieved by modern-day leaders in the thick of the global financial crisis.

More significantly, Brown emphasised the global causes of the United Kingdom's financial troubles and thereby shifted what in Chapter 2 of this volume was termed the 'policy game' to an international battlefield in which the Conservative Party could not effectively compete (Boin et al. 2009:90-1). In doing so, Brown not only defended the status quo approach to British financial regulation, he cast himself as a 'change-oriented' player on global regulatory reform. Brown was at pains in his speech to emphasise his global financial regulation credentials, stating: 'Almost exactly 10 years ago in a speech at Harvard University I made detailed policy proposals to reshape the international financial system for the new world.'

Brown's first major speech since the collapse of Lehman Brothers and the subsequent freefall in world financial markets received a lot of media coverage. Brown's severity narrative encountered some disagreement in The Guardian and The Times and he was criticised for failing to mention that Britain was heading towards recession. Brown's causality narrative, in which he exogenised blame and failed to accept that he or the British regulatory structure had a role in causing the crisis, was refuted by all three major papers. Despite this, in all three papers Brown was praised for taking a leading role in the Europe-wide fiscal stimulus and reports were cautiously optimistic about Brown's ability to lead on global regulatory reform - which they all agreed was the key to preventing another major global financial crisis.

\section{October 2008: Darling's focus on global economic governance}

The Mais Lecture is an annual speech delivered by the Chancellor of the Exchequer about the current state and future prospects of the UK economy. The 2008 Mais Lecture was delivered after the precipitous fall in world financial markets in September 2008 triggered by the US financial services firm Lehman Brothers filing the largest bankruptcy claim in US history. Domestically, the FTSE 100 had hit a five-year low and the UK Office of National Statistics had announced that Britain was on the brink of a recession. 
Unsurprisingly, Darling portrayed the severity of the crisis in starker terms than he had before September 2008. He continually emphasised the speed at which the global financial crisis had manifested and declared that 'the UK, as well as other countries, is moving into recession'. Despite Darling's portrayal of a more severe crisis, however, and economic commentators' increasingly gloomy predictions of the future, Darling neither accepted any personal responsibility for the crisis nor attributed any blame to endogenous actors. Rather, he continued to exogenise blame - focused predominately on global factors but also on the British banking industry. Darling also diminished the regulatory record of previous governments: 'looking back over 30 years of Mais lectures, I see many attempts to find solutions to domestic problems. But one aspect of modern policymaking which seems to have been understated is the impact of global events.'

Darling criticised the global economic governance system led by the major international financial institutions (IFIs), and even accepted blame, albeit very indirectly, as he claimed that the world's major nations had 'for too long....acted as an elite'. This criticism of the 'world's major nations', which undoubtedly included Britain, was noteworthy in so much as it was an angle completely absent from Brown's crisis-exploitation narrative. It appeared that Darling was diffusing blame across the major economies, thereby accepting slightly more blame on the Labour Government's behalf than the Prime Minister, although indirectly and still very little. Darling claimed that the radical fiscal stimulus was not an admission of the failure of the 'marketist' economic paradigm that the government had adhered to since 1997. Rather, Darling portrayed it as a logical development and renewed his commitment to open markets, referencing economist J. M. Keynes: 'it is right that the conduct of policy should evolve. Just as markets change, so should policy. As Keynes said, "when the facts change, I change my mind".' Ultimately, Darling asserted that a global solution to worldwide regulatory failure was the most important policy that must be achieved in years to come.

Darling's address received a fair amount of press coverage. The Times pilloried Darling's severity narrative, describing the Mais Lecture as 'a Panglossian exercise in making the best of where we are now. It should have been subtitled a study in ambiguity' (Riddell 2008b). Darling's exogenisation of the causality of the crisis came under similarly heavy attack from the Financial Times: 'Alistair Darling tried hard last night to deflect the blame from his immediate predecessor for scrapping the rules on which Gordon Brown once rested the government's economic credibility' (Eaglesham 2008). For his policy proposals, however, Darling received sympathetic criticism from The Guardian, which claimed that the Mais Lecture was a mediocre performance constrained by the rotten legacy of Brown's chancellorship (see Guardian 2008). The Times, too, condemned Darling's address for 'its vagueness in indicating a way forward' and its failure 
on all three aspects of economic policy: fiscal, monetary and regulation (Times 2008). Overall, then, each aspect of Darling's crisis exploitation in his Mais Lecture was negatively received.

\section{January 2009: governor King's 'political' edge}

By the beginning of 2009, an interesting contextual change in the relationship between King, Darling and Brown had occurred. The crisis-exploitation narrative that had been fairly unified was becoming discordant. Amid a spiralling decline in the British economy - high joblessness, low consumer demand (reflected by record low interest rates) and a plummeting currency value - King had begun intimating that he, Brown and Darling had all been partly responsible for the emergence of the United Kingdom's financial turmoil. After Brown's announcement of a second stimulus package the day before King's speech, the press reported that King disapproved of any potential further fiscal stimulus by the government. This put Brown in a defensive position because, without the fiscal tools of handouts and tax breaks, he would have to rely more on the monetary policy of the BOE. Hence, King's statements during this period became not only discordant from Brown's, but more overtly political.

Some parts of King's crisis rhetoric remained conventional: he declared that '2009 will be a difficult year for all of us', he maintained that global factors were primarily responsible for the crisis and he portrayed the crisis as a leviathan beyond the control of any single national regulatory system. The speech was, however, in some key aspects a distinct break from King's past crisis-framing efforts. Perhaps the most salient discontinuity was King's admission that before the Northern Rock crisis there had been some failings in the UK regulatory system - a system that might have contributed to the emergence of financial strife in Britain and in which he played an integral role. King stated that it is clear that policy did not succeed in preventing the development of an unsustainable position' in which the United Kingdom now found itself. Although this was only a guarded acceptance of partial responsibility for the crisis, it stood in stark contrast with the unwavering denial of culpability that Brown and Darling had maintained since September 2007. Hence, while the earlier part of King's speech characterised the global financial crisis as being too serious for any single national regulatory authority to prevent, his admission indicated that the UK response to the global financial crisis had not been as rapid or effective as it could have been.

The speech received a considerable amount of coverage in the major newspapers. The opinion of King's severity narrative was mostly negative. All papers agreed with the now widespread public view that the crisis was the most severe in more than half a century, but disagreed with King's rose-tinted portrayal of unemployment and credit easing. In the week or so after the speech, King's causality narrative received little attention, probably because King had mentioned 
that there were flaws in the UK regulatory system during a number of doorstop interviews and press releases in the weeks before the speech. Taking into consideration the press coverage of these minor speech acts, the papers overwhelmingly agreed with what they considered a long-overdue admission of responsibility from the governor. There was not much coverage of King's policy proposals, but the Financial Times was in agreement with King that wages had to be restrained in order to combat inflation.

\section{January 2009: Brown's continued global crisis narrative}

Brown's speech of 26 January was delivered at a time when the public was becoming increasingly aware that the foundations of the UK economy were not as strong as Brown and his government had initially portrayed. The European Commission had forecast on 19 January that the UK economy would not only enter recession, it would contract significantly - by 2.8 per cent in 2009-and would then recover only marginally in 2010 (Gow 2009). Also on 19 January, Brown had announced a second stimulus package of $£ 50$ billion.

Brown's speech reflected the increasingly gloomy state of the UK economy and further maximised the severity of the global financial crisis. Brown conjured florid metaphors of 'storms' and 'hurricanes' to describe the forces battering the UK economy. Brown stated that 'the sheer scale and speed of recent events makes this no ordinary crisis'. Brown also reiterated his previous statements that promoted the UK economy as among the best equipped to endure financial turmoil, by stating that 'Britain is better placed to benefit as the storm passes'.

Brown continued to deny that the government's regulatory regime was responsible for the crisis. He witheringly described the financial regulatory regime before 1997 as archaic and asserted that only Labour's revolutionary post-1997 reforms had made British financial regulation effective. Brown declared, however, that no national regulatory framework - not even one as effective as Britain's - could have prevented the unprecedented global financial crisis. Only through an international system of financial regulation could the global financial crisis have been forestalled. The Prime Minister's policy solutions remained focused on achieving the 'radical reform of our global financial system' (Webster and Duncan 2009).

Surprisingly, the speech did not receive much press coverage; only The Times published articles relating to the Prime Minister's crisis framing in the days after the speech. The paper quoted polls showing that ' 58 per cent...of people... believe he [Brown] is refusing to acknowledge the full depth of the crisis' (Webster and Duncan 2009), and further expressed criticism for Brown's causality narrative: 'Gordon Brown is fond of emphasising that the recession is global, and that it was made in America. But as massive deleveraging takes place around the world, 
it has become clear that the UK economy was one of the most overleveraged in the world' (Times 2009a).

It is hard to gauge from the limited newspaper coverage the overall support for Brown, although the few available articles were not very supportive of him. This comports with the polls at the time, which indicated that Brown's deficit to Cameron in the polls had increased to 9-14 points, from 1-7 points just one month earlier, in December 2008 (UK Polling Report 2009).

\section{February 2009: Brown under increasing pressure}

Coming only two weeks after Brown's previous major speech act, this address was important, not for any specific shift in the framing of the UK and global financial crises, but because it provoked a significant media reaction. There were two significant contextual developments in the two weeks between speeches. First, the International Monetary Fund (IMF) had declared on 28 January that the United Kingdom would be among the countries worst affected by the global financial crisis, revising its previous forecast of a 1.3 per cent contraction to 2.8 per cent (Kollewe 2009a). Second, the BOE Governor, Mervyn King, had, since late 2008, been noticeably less critical of British banks and other financial intuitions. Instead, he had started to describe, albeit in vague terms, that the banks were not alone in their failure to prevent the crisis. This led to much media speculation that there was a rift between King and Brown.

In this speech, Brown continued to make the most of the global financial crisis and exogenise its causes. Additionally, like all of his speeches since 2007, this speech again advertised Brown's strong credentials for achieving global financial reform and made use of the same historical analogy - the creation of the Bretton Woods institutions. In fact, in this speech, he expanded the analogy of the postwar economic reconstruction by referencing the Marshall Plan and describing it as a revolutionary fiscal stimulus package that brought the European and world economies back from the brink of ruin to the longest boom in modern economic history, from 1945 until the 1973-74 global recession. Thus, the analogy could be seen as a defence of the large fiscal stimulus Brown had injected into the UK economy and also a pre-emptive justification of future fiscal stimulus by the government, which was widely believed to be forthcoming despite the injection of a second round of $£ 50$ billion stimulus into the UK financial system just weeks earlier.

In his speech to the Brookings Institution, Brown also blamed British banks for promoting a culture that rewarded short-term risk over long-term sustainability. Perhaps the most interesting aspect of this speech, however, was that for the first time Brown emerged from his hitherto position of denial to admit that there were flaws in the domestic regulatory structure. He then qualified this, however, 
with the ameliorating line that no country's regulatory system could have prevented the leviathan global financial crisis.

The three papers all agreed with Brown's appreciation that the crisis was at this point egregious. The Guardian, however, noted that Brown's realisation of the severity of the crisis was overdue, saying that his claim that Britain 'was the victim of international, specifically US, banking problems' had become a 'threadbare tale' (Kettle 2009). The Financial Times also criticised Brown's causality narrative after recent negative publicity about 'how the City of London [the hub of the financial sector] was run during Mr Brown's tenure at the Treasury' (Financial Times 2009a). The aspect of Brown's speech on which all three papers critically focused was, however, his plan to cut bonus payments from the banks that had been fully or partly nationalised. All three papers vehemently disagreed with this proposal for various reasons, ranging from The Guardian's contention that it would punish genuinely creative entrepreneurs to the Financial Times' opinion that it was a tawdry populist policy that did not address the major problems at the heart of the economy in recession. Overall, then, there was little to no support in the major newspapers for Brown's severity narrative or causality narratives, or for his policy proposals.

\section{March 2009: Darling's G20 finance ministers' meeting}

Since Darling's October 2008 speech, British economic news had been increasingly bleak. At the turn of 2009, the pound had fallen to a historic low against the euro, the jobless figure of 6 per cent was the worst in a decade, the FTSE 100 continued to fall dramatically and the $\mathrm{BOE}$ had cut interest rates to the lowest figure in the bank's 315-year history.

Darling had admitted in his October speech that the United Kingdom was headed for recession. In his address to the Foreign Press Association at the G20 Finance Ministers' Summit, however, he too put a twist on his old rhetoric of growth, saying that 'we mustn't lose sight of [the fact that] the global economy is expected to double, so there's a huge prize to be won'. This speech is notable because of its heavy use of crisis-exploitation rhetoric. It was particularly strident in identifying global factors as the primary cause of Britain's financial crisis and global re-regulation as the most important policy to achieve. Again, Darling attempted to shift debate away from the domestic battleground, where the government was being staunchly challenged by the Conservative Party, to an international arena in which the opposition, with no internationally recognised mandate to speak for the UK electorate, could not compete.

Somewhat surprisingly, there was almost no media coverage of Darling's address to the press contingent at the meeting of G20 finance ministers. As the President of the G20 in 2009, Britain had clearly embraced the G20 as a body that could effectively combat the crisis and effect global financial re-regulation. In the only 
article that dealt with Britain's role in the G20, however, The Times was dubious about the government's embrace of the G20 after ignoring the body for a number of years. 'Gordon Brown will be chairman of the summit and his enthusiasm for remaking supranational organisations almost invites mockery because the ambitions so far outstrip the amount of work that has been invested in realising them' (Times 2009b). It was noteworthy that there was a complete absence of specific coverage of Darling's speech. This suggests that his concerted crisis-exploitation efforts went largely unrecognised by the public.

\section{March 2009: King's caution against rash action}

Amid an escalation in the tension between King and Brown, visible in their media comments since January, the BOE Governor delivered his most significant speech on the continually worsening effects of the global financial crisis. Newspapers had widely reported that UK unemployment had reached a 12-year high of two million people (Hopkins 2009a) and the BOE had again slashed interest rates to another historic low, of 0.5 per cent. This speech, again, represented another shift away from the crisis-exploitation rhetoric of Brown to which King had closely adhered between September 2007 and late 2008.

As in his previous speeches, King maximised the severity of the crisis. At the same time, however, King downplayed the urgency required for the next response to the stagnating - if not worsening - financial situation and instead advised that all key leaders take time to choose the right course of action. This could have been directed at Brown, who had already approved a number of fiscal stimulus packages, as just one week later, on 24 March, King sensationally announced that further fiscal stimulus by the government was inadvisable (Duncan and King 2009; Hopkins 2009b; Wintour 2009).

King's causality narrative became more nuanced in this speech. King again identified global forces as the primary cause of the crisis - particularly the poor performance of IFIs and the absence of a global regulatory order. King added another layer, however, to his imputation of blame to global forces by criticising the role of creditor and debtor nations in the crisis. He criticised creditor nations for loaning money without pressuring debtor nations to repay and pilloried debtor nations for naively borrowing massive amounts of money, prolonging their repayments and racking up significant public debt. From this criticism, he did not exempt the United Kingdom, which, in Organisation for Economic Cooperation and Development (OECD) terms, had neither high nor low public debt (CIA 2009b).

There was no media coverage of King's severity narrative or the new strand about creditor and debtor nations in his causality narrative. Only the Financial Times addressed King's causality narrative in any detail, taking issue with King's excuse that his inflation targets had not worked because he did not have adequate 
power to achieve them. Instead, the paper accused King of being a key part of a short-sighted hierarchy that had not adequately prepared for a financial downturn when the economy was booming (Giles 2009). 'In reality, all three institutions in the so-called tripartite arrangements for financial supervision were culpable in failing to recognise the toxic combination of rapid credit expansion and financial innovation' (Stephens 2009).

There was, conversely, a plethora of coverage of King's policy proposals. The papers were unified in their praise for King's proposals to abolish the banks' 'casino' lending and gambling practices as well as his subtle suggestions for the Prime Minister to avoid further fiscal stimulus. The majority of articles in these three papers, however, criticised King for his pessimism and for talking down the UK economy. King was also criticised for failing to admit that the BOE- not just the FSA and the Treasury-needed to undergo reform to prevent future crises.

\section{Framing the financial crisis in the United Kingdom: analysis and conclusions}

It was not until the precipitous falls in financial markets through mid 2008 that the global financial crisis manifested in the United Kingdom. Since September 2007, however, the financial turmoil in Britain has been a historic affair. The British public, more so than the populaces of countries whose economies began visibly struggling only in mid 2008 after the collapse of Lehman Brothers, had become more attuned to news of the worsening financial turmoil.

\section{Naming, explaining and accounting for the crisis}

At first sight, Brown's, Darling's and King's labelling and explanation of the financial turmoil of 2007-09 followed similar paths. The severity narratives of Brown and Darling were so similar in their progression towards ever-starker characterisations as to suggest a high level of coordination between the two. There was, however, a noteworthy inconsistency among the three actors' severity narratives. Brown and Darling initially engaged in minimisation, stating from late 2007 and throughout 2008 that the United Kingdom was in a distinctly strong economic position to confront the financial crisis. King, on the other hand, did not engage in any such minimisation.

The three actors' causality narratives, and the attendant task of accepting or denying blame, were fairly consistent. From the outset, they all emphasised global factors as the primary cause of the United Kingdom's financial turmoil. Again, the causality narratives of Brown and Darling were similar to one another while King's account diverged in a few small, but key ways. First, whereas Brown and Darling initially failed to admit flaws in their handling of the Northern Rock crisis, King in November 2007 absorbed minimal blame, claiming that, if he had his time again, he would have responded differently to Northern Rock's 
predicament. Second, in late 2008, King began to eschew specifically identifying global factors or British financial institutions as causing the crisis. Instead, he described in vague tones that they were not alone in acting irresponsibly during the pre-2007 period of high world economic growth. This suggests that King was admitting, albeit indirectly, that he and other regulators-but more significantly, the Prime Minister and the Chancellor - had played a part in the escalation of the crisis. Third, King added another unique strand to his causality narrative by blaming not just international financial institutions or a lack of global financial regulation, but debtor economies such as the United Kingdom, which had complacently relied on easy credit.

It appeared that King's blunt criticism prompted Brown and Darling to admit in February 2009 that there had been flaws in the regulatory system before the global financial crisis. The press, however, interpreted these admissions as cynical 'road-to-Damascus' conversions that were a reaction to King and a pre-emption of the late-March release of the Turner Review, an official government review on the state of the UK financial regulatory system before September 2007 and those most responsible for its creation. King's late-2008 departure from the causality and blame narratives of Brown and Darling presented an interesting intra-regime framing contest. This contest contributed to the greater framing contest between the three actors: the Labour Government (along with the supposedly apolitical BOE Governor, who was likely to cooperate with the incumbent government), the opposition Conservative Party and the media.

\section{Framing contests: political survival and policy reform}

To examine the larger framing contest, it is broken down into two distinct contests that have most influenced the political game over issues of responsibility: between the government and the opposition (parliamentary and extra-parliamentary); and the policy game over reform: between proponents of the status quo and change advocates (cf. Table 2.2 in Chapter 2).

Contests over policy framing can be separated into the domestic and international battlegrounds. Both stemmed from the causality narrative of the political actors Brown and Darling - and to a lesser extent the non-partisan technocrat King — who argued that the United Kingdom's financial turmoil was caused primarily by global factors. The domestic policy-framing contest was over the injection of $£ 300$ billion into the financial system - Brown and Darling's response to the global financial crisis. Brown and Darling depicted this sizeable and highly statist fiscal stimulus as absolutely necessary. More significantly, the framing contest centred on implications for existing British financial regulation policies. Brown and Darling had argued that the British regulatory structure was world class and revolutionary by British standards; that even this could not prevent the leviathan global financial crisis hitting British shores; and that policy implications should be minimal because Britain's crisis was caused predominately 
by global problems. In terms of the crisis-framing typology of Chapter 2, Brown and Darling clearly adopted on the domestic battleground a type-2 frame in which the crisis was viewed as a 'critical threat to the collective good embodied in the status quo' and as such the status quo must be defended against critics.

As argued in Chapter 2, such a type-2 defence is typical of incumbents. For Brown and Darling, it was a logical frame to adopt. Labour, a long-serving government, was unpopular in the electorate and, like many long-serving governments, it appeared to aspire to short-term regime survival. By denying responsibility for the crisis for so long, however, the two political actors set up a 'blame showdown' in which they might escape political repercussions, but are more likely to suffer political damage (see Table 2.1, Chapter 2). In the international policy reform game, however, the government sidestepped the role of status quo defender and cast itself decisively as a change-oriented player.

Brown and Darling seized the political opportunity afforded to them by the exogenous-causality narrative and declared that the most important policy outcome of the global financial crisis should be the complete restructuring of the global regulation of finances. They unified and strengthened their type- 3 rhetoric (focusing blame and attacking the status quo) by deploying historical analogies that affirmed the benefits of global financial re-regulation, notably the reference to the creation of the Bretton Woods system. In their declaration to the public that they and their Labour cabinet colleagues were best credentialled to achieve such global regulatory reform, Brown and Darling adopted, on the international battleground, type- 3 frames, which regarded the crisis as 'a critical opportunity to expose deficiencies in the status quo ex ante' (see Chapter 2).

Adding to this intricate combination of type- 2 and type- 3 frames, the defence of the government's open and globalised economic approach by each of the three main UK actors placed the Conservative opposition in a difficult political position. As The Guardian's Economics Editor Larry Elliot suggested, the government's defence of its marketist approach, combined with its calls to re-regulate the global economy, put the Conservative Party in an awkward position because the 'Conservative Party [has] obviously much more of a [marketist] deregulatory bent than Labour in historic terms' (Elliot 2008b). Labour used its centrist 'third way' ideology as a means of wedging the Conservative Party on its key policy proposals - maintaining open and globalised markets and re-regulating the global economy.

Brown and Darling's multilayered framing strategy - a type-2 frame defending the domestic status quo; a type- 3 frame portraying the government as a change-oriented player; and a defence of marketism and global re-regulation - seemed set for success. The fact that the press and public largely agreed with Brown and Darling's claims that global factors were the primary 
cause of Britain's financial turmoil appeared to have made the international framing contest one that put the incumbents in an advantageous political position. Nonetheless, the framing contest most important for the political fortunes of the government and their parliamentary opposition was the domestic one. While the press agreed that global factors were primarily responsible for the United Kingdom's financial turmoil, they reacted vehemently against Brown and Darling's long-time denial of responsibility for the crisis. The later concessions by the Prime Minister and the Chancellor that they were responsible for some flaws in the British regulatory structure further damaged their government's popularity (UK Polling Report 2009). This development fits with the claims of Boin et al. (2005:86-7) that actors who belatedly admit responsibility for a crisis suffer far more damage than those who absorb minimal blame early in the crisis. While the three actors' assertions that the domestic financial turmoil was caused primarily by global factors was supported by the press and public, Brown and Darling's long-time denial of culpability for the emergence of the crisis and their defence of the status quo domestic financial regulation was overwhelmingly rejected by the electorate. This left them in March 2009 far behind in the polls with just more than a year before the compulsory date for the next national election.

For King, it appears as though he suffered only minor damage to his credibility. This appears to be a result of two factors: his acceptance of minimal blame for the Northern Rock and the British financial crisis in general; and the general view that he is not technically a political player. King was not required to engage as much as Brown or Darling in the key task of managing the public's expectations about the crisis; as such, he could instead focus on providing technical explanations and solutions for Britain's financial crisis. This is not to say that King is apolitical. The Governor of the BOE became politicised by his own doing - specifically, by implying that endogenous actors were responsible for the crisis and, more significantly, by publicly halting the government's plans for a further fiscal stimulus. King's divergence from his previous line of crisis rhetoric - which had been fairly concordant with that of the Prime Minister and the Chancellor - was hardly inspired by political motives. He was up for reappointment to the second of a maximum two-term tenure in January 2008, which he duly received regardless of his 'inconvenient' stance on the issue of responsibility for the financial crisis.

A general observation that can be drawn from the UK case study, and that might even apply to all case studies in this volume, is that financial crises, by nature, appear to require governments to talk up and support the national economy in the incubation period of the crisis, at the expense of locking themselves into a specific frame. If key government actors are aware that financial turmoil is likely to hit their nation's economy, they are likely to downplay the severity in an 
attempt to maintain consumer confidence and curb the damage of a potential crisis. If they do not do this, they can easily be blamed for exacerbating any financial crisis that hits the nation.

The response to the British manifestation of the global financial crisis comports with the proposition that long-serving governments find it difficult to convince the public that they are fit to make the changes necessary to prevent another crisis in the future. The findings from this chapter, however, suggest that the chances of long-serving governments flourishing in a financial crisis are made even more remote by their necessary but risky obligation to talk up the national economy in the incubation period of the crisis.

\section{References}

$B B C$ 2007, 'UK families put on fraud alert', $B B C$ News, 20 November, viewed 4 April 2009, <http://news.bbc.co.uk/2/hi/uk_news/politics/7103566.stm>

$B B C$ 2009, 'Timeline: global credit crunch: a quick guide to the origins of the global financial crisis', BBC News, 3 April, viewed 20 April 2009, $<$ http://news.bbc.co.uk/2/hi/business/7521250.stm>

Boin, A., 't Hart, P., Stern, E. and Sundelius, B. 2005, The Politics of Crisis Management: public leadership under pressure, Cambridge University Press, Cambridge.

Boin, A., 't Hart, P. and McConnell, A. 2009, 'Crisis exploitation: political and policy impacts of framing contests', Journal of European Public Policy, vol. 16, no. 1, pp. 81-106.

Brown, G. 2007, Speech on the global economy at the Reuters Building, 1 October, viewed 28 March 2009, <http://www.number10.gov.uk/Page13355>

Brown, G. 2008, Speech on the global economy at the Reuters Building, 13 October, viewed 28 March 2009, $<$ http://www.number10.gov.uk/Page17161>

Brown, G. 2009a, Speech on global economic crisis, 26 January, viewed 30 March 2009, <http://www.number10.gov.uk/Page18153>

Brown, G. 2009b, Q\&A session on the global economy with the Brookings Institution, 9 February, viewed 30 March 2009, <http://www.number10.gov.uk/Page18266>

Central Intelligence Agency (CIA) 2009a, Country Comparisons: GDP (purchasing power parity), Central Intelligence Agency, 14 May, viewed 29 May 2009, <https://www.cia.gov/library/publications/ the-world-factbook/rankorder/2001rank.html> 
Central Intelligence Agency (CIA) 2009b, Rank Order-Public debt, Central Intelligence Agency, 14 May, viewed 30 May 2009, $<$ https://www.cia.gov/library/publications/ the-world-factbook/rankorder/2186rank.html>

Darling, A. 2007a, Speech at the Reuters Building, 1 October, UK Treasury, viewed 1 April 2009, <http://www.hm-treasury.gov.uk/speech_chex_011007.htm>

Darling, A. 2007b, Speech to the CBI Conference, 27 November, UK Treasury, viewed 1 April 2009, $<$ http://www.hm-treasury.gov.uk/speech_chex_271107.htm>

Darling, A. 2008a, Speech to the Royal Society for the Encouragement of the Arts, Manufacturers and Commerce, 15 January, UK Treasury, viewed 2 April 2009, <http://www.hm-treasury.gov.uk/press_03_08.htm>

Darling, A. 2008b, Speech to the Worshipful Society of International Bankers, 4 February, UK Treasury, viewed 2 April 2009, $<$ http://www.hm-treasury.gov.uk/speech_chex_040208.htm>

Darling, A. 2008c, Chancellor of the Exchequer's budget statement, 12 March, UK Treasury, viewed 12 May 2009, <http://www.hm-treasury.gov.uk/bud_bud08_speech.htm>

Darling, A. 2008d, The Mais Lecture on maintaining stability in a global economy, 12 October, UK Treasury, viewed 3 April 2009, <http://www.hm-treasury.gov.uk/press_110_08.htm>

Darling, A. 2009, Address to the Foreign Press Association at the G20 Finance Ministers' Summit, 11 March, UK Treasury, viewed 2 April 2009, $<$ http://www.hm-treasury.gov.uk/speech_chex_110309.htm>

Duncan, G. and King, I. 2009, 'Mervyn King: UK can't afford any more stimulus plans', Times Online, 24 March, viewed 26 March 2009, $<$ http://business.timesonline.co.uk/tol/business/economics/article5966450.ece>

Eaglesham, J. 2008, 'Chancellor tries hard to deflect blame', Financial Times, 30 October, p. 2.

Elliot, L. 2007, 'Let's not rush to enter Virgin territory', The Guardian, 27 November, viewed 27 March 2009, $<$ http://www.guardian.co.uk/business/2007/nov/27/ northernrock.creditcrunchl>

Elliot, L. 2008a, 'Brown mannerisms, rose-tinted forecasts but few green measures', The Guardian, 13 March, viewed 27 March 2009, <http://www.guardian.co.uk/commentisfree/2008/mar/13/ budget.alistairdarling/print> 
Elliot, L. 2008b, 'Video commentary on Alistair Darling's speech to Labour Party conference', The Guardian, 22 September, viewed 27 March 2009, <http://www.guardian.co.uk/politics/video/2008/sep/22/darling >

Financial Times 2009a, 'Brown's chance to save himself', Financial Times, 13 February, viewed 19 May 2009, <http://www.ft.com/cms/s/8e4b3ac2-fa09-11dd-9daa-000077b07658>

Financial Times 2009b, 'About us', Financial Times, 17 June 2009, viewed 17 June 2009, <http://www.ft.com/aboutus>

Galloway, G. 2006, 'Interview by Kieran Meeke', Metro UK, 28 April, viewed 4 April 2009, <http://www.metro.co.uk/fame/interviews/ article.html?in_article_id=12486\&in_page_id=11>

Giles, C. 2009, 'King back in his castle', Financial Times, 28 March, p. 9.

Gow, D. 2009, 'European Commission predicts UK economy will shrink by $2.8 \%$ ', The Guardian, 19 January, viewed 21 May 2009, $<$ http://www.guardian.co.uk/business/2009/jan/19/european-economic-forecast>

Guardian 2008, 'Throwing out the rulebook', The Guardian, 30 October, viewed 5 April 2009, <http://www.guardian.co.uk/commentisfree/2008/oct/30/ economy-darling-crunch-government-borrowing >

Guardian 2009, 'ABCs: national daily newspaper circulation January 2009', The Guardian, 6 February, viewed 28 May 2009, <http://www.guardian.co.uk/media/table/2009/feb/06/ abcs-january-national-newspapers $>$

Hopkins, K. 2009a, 'UK unemployment nears 2 million', The Guardian, 11 February, viewed 6 May 2009, <http://www.guardian.co.uk/business/2009/feb/11/ uk-unemployment-job-losses $>$

Hopkins, K. 2009b, 'Britain cannot afford any further fiscal stimulus, King warns', The Guardian, 24 March, viewed 26 March 2009, <http://www.guardian.co.uk/business/2009/mar/24/ bankofenglandgovernor-banking/print>

Ipsos Mori Poll 2005, 'Voting intention by newspaper readership quarter 1', Ipsos Mori Poll, 21 April, viewed 28 May 2009, <http://www.ipsos-mori.com/content/polls-05/ voting-intention-by-newspaper-readership-quarter-1.ashx $>$

Kaletsky, A. 2008, 'Fingers crossed, Darling: budget 2008', The Times, 13 March, p. 1.

Kettle, M. 2008, 'In defence of Darling', The Guardian, 18 February, viewed 27 March 2009, 
Framing the global economic downturn

$<$ http://www.guardian.co.uk/commentisfree/2008/feb/18/ indefenceofdarling/print>

Kettle, M. 2009, 'Now Brown has to accept his share of guilt for the mess', The Guardian, 13 February, viewed 26 March 2009, $<$ http://www.guardian.co.uk/commentisfree/2009/feb/13/ gordon-brown-financial-crisis/print $>$

King, M. 2008a, Speech at the dinner hosted by the CBI and the IoD South West, 22 January, Bank of England, viewed 4 April 2009, $<$ http://www.bankofengland.co.uk/publications/speeches/2008/speech333.pdf $>$

King, M. 2008b, Speech to the British Bankers Association, 10 June, Bank of England, viewed 5 April 2009, $<$ http://www.bankofengland.co.uk/publications/speeches/2008/speech347.pdf >

King, M. 2009a, Speech to the CBI dinner, 20 January, Bank of England, viewed 5 April 2009,

$<$ http://www.bankofengland.co.uk/publications/speeches/2009/speech372.pdf $>$

King, M. 2009b, A return from risk, Speech to the Worshipful Society of International Bankers, 17 March 2009, Bank of England, viewed 6 April 2009,

$<$ http://www.bankofengland.co.uk/publications/speeches/2009/speech381.pdf $>$

Kollewe, J. 2009a, 'IMF: UK economy will be hardest hit in the worst recession since second world war', The Guardian, 28 January, viewed 23 May 2009, <http://www.guardian.co.uk/business/2009/jan/28/ ilo-global-unemployment-to-soar>

Kollewe, J. 2009b, 'Bank of England cuts rates to $0.5 \%$ and starts quantitative easing', The Guardian, 5 March, viewed 6 April 2009, $<$ http://www.guardian.co.uk/business/2009/mar/05/ interest-rates-quantitative-easing $>$

Morley, I. 2007, 'Darling is throwing out baby, water and bathtub', Financial Times, 26 November, p. 11.

Mulholland, H. 2008, 'Ed Balls issues veiled threat to David Miliband over Labour leadership', The Guardian, 1 September, viewed 4 April 2009, $<$ http://www.guardian.co.uk/politics/2008/sep/01/labourleadership.labour>

Pratley, N. 2007, 'Rock run finds Bank and Darling off the pace', The Guardian, 18 September, viewed 2 April 2009, $<$ http://www.guardian.co.uk/business/2007/sep/18/politics.money>

Riddell, P. 2008a, 'With the public in such a gloom, could this be Labour's point of no return', The Times, 20 March, p. 28. 
Riddell, P. 2008b, 'Chancellor is glossing over the crucial questions', Times Online, 30 October, viewed 27 April 2009, <http://www.timesonline.co.uk/tol/comment/columnists/ peter_riddell/article5042498.ece>

Seager, A. 2009, 'Mervyn King refuses to apologise for not spotting recession', The Guardian, 11 February, viewed 24 April 2009, <http://www.guardian.co.uk/business/2009/feb/11/ bank-of-england-inflation-report>

Stephens, P. 2008, 'The bad news Darling can't banish', Financial Times, 12 March, p. 5.

Stephens, P. 2009, 'Autocratic leadership has failed the Bank of England', Financial Times, 30 March, viewed 21 April 2009, $<$ http://www.ft.com/cms/s/0/ la885002-1d59-11de-9eb3-00144feabdc0.html>

Sunderland, R. 2007, 'Gordon needs to parcel up the Rock before Christmas', The Guardian, 18 November, viewed 27 March 2009, <http://www.guardian.co.uk/business/2007/nov/18/ comment.businessandmedia/print>

Times 2007, 'Poll tracks anger over data loss', The Times, 23 November, viewed 30 May 2009,

<http://www.timesonline.co.uk/tol/news/politics/article2926574.ece>

Times 2008, 'Lost in the Mais', The Times, 30 October, viewed 27 April 2009, $<\mathrm{http}$ ://www.timesonline.co.uk/tol/comment/leading_article/article5042273.ece>

Times 2009a, 'The pounding of the pound', The Times, 21 January, viewed 24 April 2009, $<$ http://www.timesonline.co.uk/tol/comment/leading_article/article5556168.ece>

Times 2009b, 'A summit for stimulus', The Times, 14 March, p. 2.

UK Polling Report 2009, 'Voting intention since 2005', UK Polling Report, 20 May, viewed 29 May 2009, $<$ http://ukpollingreport.co.uk/blog/voting-intention>

Webster, P. and Duncan, G. 2009, 'D-Day for Brown as he says world is already in a depression', The Times, 5 February, p. 7.

Wintour, P. 2009, 'Mervyn King's economic assessment will infuriate Downing Street - but will be warmly welcomed by Treasury', The Guardian, 25 March, viewed 26 March 2009, <http://www.guardian.co.uk/politics/2009/mar/25/ treasury-borrowing-mervyn-king/print> 